\title{
Comparative Study of Selenium and Zinc Antioxidant in HIV Sero Positive Individuals
}

\author{
Ibiene Sarah Kalio \\ School of Medical Laboratory Science Rivers State College of Health Science and Technology, Rumueme, PMB \\ 5047, Port Harcourt, Rivers State, Nigeria.
}

\begin{abstract}
Antioxidant like Selenium and Zinc trace elements are usually reduced in HIV/AIDS patients but the difference in deficiency between the two trace element is not known. This study was carried out to determine Selenium and Zinc trace element in HIV positive individuals. Serum Selenium, Zinc, albumin and total protein concentration of twenty five HIV positive individuals were compared with twenty five HIV negative individuals. Atomic absorption spectrophotometric method was used to determine concentration of Selenium and Zinc while Bromocresol green method and Biuret method were used to determine albumin and total protein respectively. The result showed that mean \pm standard deviation for Selenium was $31.76 \pm 1.13 \mathrm{mg} / \mathrm{L}$, zinc was $0.46 \pm$ $0.10 \mathrm{mg} / \mathrm{L}$, albumin $33.18 \pm 12.61 \mathrm{~g} / \mathrm{L}$ and total protein $31.35 \pm 9.05 \mathrm{~g} / \mathrm{L}$ in HIV positive individuals while the control includes selenium $75.15 \pm 1.93 \mathrm{mg} / \mathrm{L}$, zinc $1.56 \pm 1.46 \mathrm{mg} / \mathrm{L}$, albumin $39.68 \pm 13.2 \mathrm{~g} / \mathrm{L}$ and total protein61.22 $\pm 26.85 \mathrm{~g} / \mathrm{L}$ respectively. This study showedthat HIV positive individuals exhibit greater deficiency in zinc than in Selenium $(p<0.05)$. This difference can be attributed to compensatory antioxidant response to HIV by Selenium in well nourished HIV subjects.
\end{abstract}

Keywords:Antioxidant, free radical, trace elements, zinc, Selenium, total protein, albumin.

\section{Introduction:}

Antioxidant refers to vitamins, enzymes and minerals which protect the human body from the chain reaction caused by free radicals. Deficiencies in antioxidants during HIV infection help to increase the development of oxidative stress thereby increasing the chance for immune dysregulation and HIV replication (Allard et al., 1998).

Selenium is a trace element nutrient found in Brazil nuts, corn and wheat. It functions as a co-factor for the reduction of antioxidant enzymes such as glutathione peroxidase. Low Selenium concentration have been described in a number of chronic diseases such as HIV/AIDS (Rayman, 2000), myocardial infarction, severe burns, acute pancreatitis and intensive care patients (Hawker et al., 1990). However, Selenium deficiency has also been suggested to aid the increase susceptibility to cancer and cardiovascular diseases (Arthur and Beckett, 1994).

Baum et al., (1997), reported high risk of HIV related mortality due to selenium deficiency. While Kruzich et al., (2004) reported reduce rate of HIV hospitalized patients admission due to Selenium supplementation.

Selenium trace element is incorporated into proteins to make selenoproteins which are important antioxidant enzymes. The antioxidant activities of some selenoproteins help prevent free radical damage (Palm and Paulson, 1997).

Zinc an essential mineral found in oysters supplies antioxidant activity, optimizes vision and eye health, healthy skin and supports immune system (Maret and Sandstead, 2006). Although zinc is a component of a lot of mammalian metallo-enzymes, it has been associated with HIV (Prasad, 1993). Zinc plays specific roles as an antioxidant, immune modulator (Tanakaet al., 1990) and a possible direct antiviral agent (Favier, 1994). Incidence of zinc deficiency in HIV infection has been documented in multiple studies (Flavier et al., 1992).

Beach et al., (1992) reported marginally low zinc levels in asymptomatic HIV-1 seropositive patients without history of alcoholism or clinical evidence of nutritional deficiencies. In zinc deficiency, $\beta$ cells which represent main cells of humoral immunity and T cells are reduced (Moulder, 1989; Stanbullian et al., 2007; Eddeset al., 1996).

Zinc and Selenium are trace elements that aid in antioxidant activity and are important for maintaining a healthy immune system (Khalili et al., 2008). These trace elements are usually reduced in HIV/AIDS patients. Hence, a comparative study of this reduction between Selenium and zinc in HIV needs to be determined.

This study sought to make a comparative study of Selenium and Zinc antioxidant in HIV seropositive individuals by determining selenium and zinc concentration. 


\section{Materials and Method}

Twenty five HIV positive individuals attending the outpatient clinic of the University of Port Harcourt Teaching Hospital, Rivers State of Southern Nigeria were used as test subjects, while twenty five HIV negative individuals from the surrounding community served as control. Pregnant women, children, hospitalized HIV positive individuals, individuals suffering from diabetes, intestinal problems, kidney problems and tuberculosis were excluded to avoid their influence on Selenium and zinc level.

Five millimeters of blood samples were collected from participants to obtain serum samples. Samples were screened for HIV antibodies by using Determined HIV Rapid Test and confirmed with Uni-Gold ${ }^{\mathrm{TM}}$ Recombigen ${ }^{\circledR}$.

Selenium and zinc were determined in samples using uniscope AA $320 \mathrm{~N}$ atomic absorption spectrophotometry (AAS). Bromocrosol green method and Biuret method were used to determine Albumin and total protein respectively.

\section{Result}

The result showing the concentration of selenium and zinc antioxidant in twenty five HIV positive individual and twenty five HIV negative individual is summarized below:

Table 1:Result of concentration of selenium and zinc antioxidant with statistical evaluation (n=25) for HIV positive individuals and $(n=25)$ for control.

\begin{tabular}{|l|l|l|l|}
\hline Parameter & $\begin{array}{l}\text { HIV } \\
(\text { mean } \pm \text { SD) }\end{array}$ & $\begin{array}{l}\text { Control } \\
(\text { mean } \pm \text { SD) }\end{array}$ & P Value \\
\hline Selenium $(\mathrm{mg} / \mathrm{l})$ & $31.76 \pm 1.13$ & $75.15 \pm 1.93$ & $\mathrm{P}<0.05$ \\
\hline Zinc $(\mathrm{mg} / \mathrm{l})$ & $0.46+0.10$ & $1.56 \pm 1.46$ & $\mathrm{P}<0.05$ \\
\hline Albumin $(\mathrm{g} / \mathrm{l})$ & $33.18 \pm 12.61$ & $39.68 \pm 13.21$ & $\mathrm{P}<0.05$ \\
\hline Total Protein $(\mathrm{g} / \mathrm{l})$ & $31.35 \pm 9.05$ & $61.22 \pm 26.85$ & $\mathrm{P}<0.05$ \\
\hline
\end{tabular}

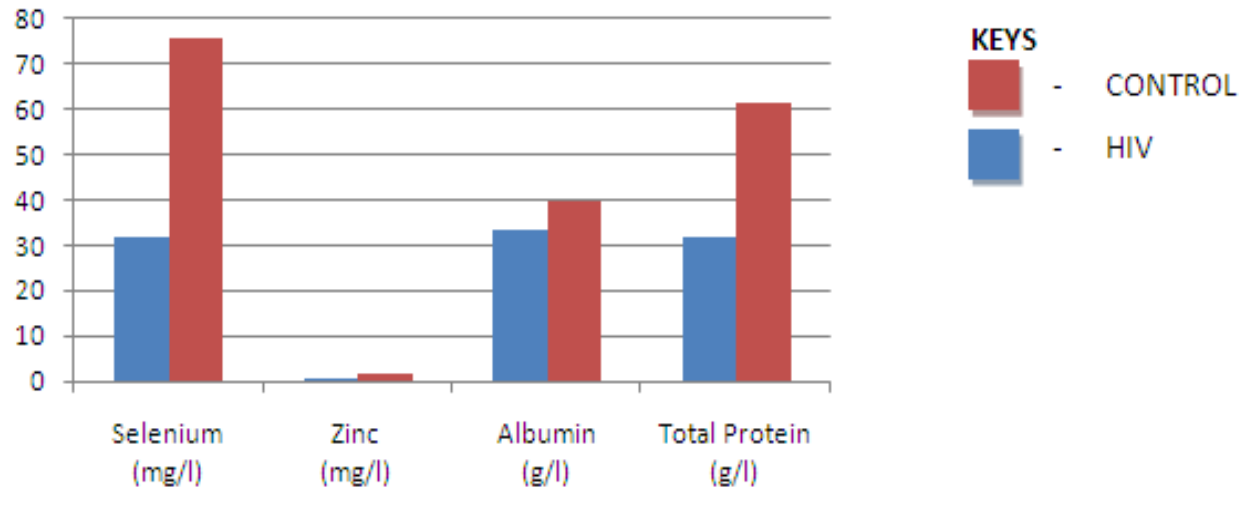

Fig. 1: Selenium and Zinc in HIV positive individual and control with $\mathbf{n}=\mathbf{2 5}$ for positive individuals and $\mathbf{n}=\mathbf{2 5}$ for control

The result of this study showed significant difference in the mean Selenium $(\mathrm{mg} / \mathrm{L})$ concentration of $31.76 \pm 1.13 \mathrm{mg} / \mathrm{L}$ in $\mathrm{HIV}$ positive individuals and $75.15 \pm 1.93 \mathrm{mg} / \mathrm{L}$ in HIV negative individuals $(\mathrm{P}<0.05)$. Also, there was significant difference in zinc $(\mathrm{mg} / \mathrm{L})$ concentration of $0.46 \pm 0.10 \mathrm{mg} / \mathrm{L}$ in $\mathrm{HIV}$ positive individuals and $1.36 \pm 1.11 \mathrm{mg} / \mathrm{L}$ in HIV negative individuals $(\mathrm{P}<0.05)$. Total protein of $31.35 \pm 9.05 \mathrm{~g} / \mathrm{l}$ in HIV positive individuals was significantly lower than control61.22 $\pm 26.85 \mathrm{~g} / \mathrm{l}$. All four parameters were higher in HIV negative individuals than HIV positive individuals as shown in table 1 and figure 1 above. Zinc concentration was significantly lower in HIV patients than in control but was much lower than selenium in HIV positive individuals $(\mathrm{P}<0.05)$

\section{Discussion}

In this study, serum selenium concentration was significantly reduced in HIV positive individuals than HIV negative individuals similar to the finding of Khalili et al., (2002) when they examined nutritional status, serum zinc and selenium in Iranian HIV infected individuals, and attributed low concentration to malnutrition.

Grunfield et al., (1992) attributed low selenium to low selenium oxidative state induce by HIV, malabsorption, altered metabolism, gut infection, altered gut bearer function and hyper metabolic state produced by 
chronic HIV infection. Shisler et al.,(1998) suggested that depletion of selenium can be as a result of utilization of selenium by HIV-1 virus to produce its own seleno enzymes.

Horik et al.,(1997) suggested that supplementation of selenium may increase the activities of cellular antioxidant glutathione peroxidase and hence prove beneficial as an adjuvant therapy for AIDS.

In this study, serum zinc concentration was significantly reduced in HIV positive individuals than control. This reduction is consistent with the findings of William et al., (2006) who reported low concentration of zinc in AIDS patients and HIV seropositive individual. They attributed decrease serum zinc level in out AIDS patients to presence of acute infection and zinc's role as an acute phase reactant while in clinical AIDS patients; they attributed the decrease zinc level to opportunistic infection. This decrease in serum zinc level contradicts the finding of Licastro et al., (1995) who found normal plasma zinc level in healthy elderly donors.

Reduction in selenium and zinc is consistent with the work of Allavena et al., (1995) who documented reduce selenium and zinc level in HIV.

In this study serum Albumin concentration is lower in HIV positive individuals than control which agrees with the work of Khalili et al., (2008) who documented low serum Albumin concentration in HIV patients and disagrees with the work of Stanbullian et al.,(2007) who reported normal albumin concentration in HIV seropositive patients.

According to Giray et al., (1985), serum total protein estimation has little importance in diagnosis when compared to albumin. This is as a result of compensatory increases observed in other serum protein during infection. Decrease in total protein level in HIV patients observed in this study may be attributed to increase losses and or catabolism due to side effects from medication, reduced intake, reduced absorption due to sores in mouth and fatigue which agrees with the work of Macallan,(1999). Normal serum total protein in control can be attributed to nutritional intake and reduce losses in the intestinal tract.

Reduction in all four parameter is consistent with the work of Khalili et al., (2008). In this study HIV positive individuals exhibited greater deficiency in zinc than in selenium. This difference can be attributed to compensatory antioxidant response to HIV by selenium in well nourished HIV subjects who have better improved selenium - dependant antioxidant defenses.

In conclusion, antioxidants like selenium and zinc are more reduced in HIV patient than the control group. It is suggested that further study be carried out to make a comparative study of selenium and zinc at different stages of HIV infection.

\section{References}

[1]. Allard, J.P., Aghdass, I. E., Char, J., Salit, I. and Walmsley, S. (1998). Oxidative stress and plasma antioxidant micronutrients in humans with HIV infection. Am.J. Clin Nutri. 67:143-147.

[2]. Allavena, C., Dousset, B., May, J., Dubois, P., Canton, F., and Belleville (1995). Relationship of trace element, immunological markers, and HIV- 1 infection progression. Biological trace element Research 101, 47(1-3): 133-138

[3]. Arthur, J. P. and Beckett, G.J. (1994). Newer aspects of micronutrients in risk group, New Metabolic roles of selenium. Proc. Nutr. Soc. 53:615-624.

[4]. Baum, M. K., Shor-Posner, G. and Lai, S. (1997). High risk of HIV - related mortality is associated with selenium deficiency. J Acquire Immune Deficiency Hon. Retrohirol 15:370-4.

[5]. Beach, R., Mantero - Atienza, E., and Shor-Posner, G, (). Specific nutrient abnormalities in asymptomatic HIV-1 infection. AIDS, 6:701-708.

[6]. Delmas - Beaurieux, M. C., Peuchant, E. and Couchouron, A. (1996). The enzymatic antioxidant system in blood and glutathione status in human immunodeficiency virus (HIV) - infected patients: effect of supplementation with selenium or beta-carotene. Am. J. Clin. Nutr. 64:101-107

[7]. Dworkin, B.M., Rosenthal, W.S., Wormser, G. P. and Weiss, L. (1986). Selenium deficiency in the acquired immunodeficiency syndrome. J. Parenter Enteral Nutr. 10:405-407.

[8]. Edess, M. A., Peltier, K., Claise, C., Khalfoun, Y and Linderbaun, A. (1996).Immunocytochemical study of uptake of exogenous carrier free copper-zinc superoxidase dismutase by peripheral blood lymphocytes. Cell Mol. Biol 42:137-1143.

[9]. Favier, A., Sappey, C. and Leclere, P. (1994).Antioxidant status and lipid peroxidation in patients infected with HIV. Chem. Biol. Interact, 91:165-180.

[10]. Favier, A.O.M. (1992). The role of zinc in acquired immunodeficiency syndrome. J. Intern. Med: 231:463-469.

[11]. Gray, C. H., Howorth,P. N.and Rinster, M. G. (1985).In plasma protein and immunoglobobins, clinical chemical pathology $10^{\text {th }}$ Edition, Edward Arnord (Publishers) Ltd, Bledford, London, Pp 73-89.

[12]. Grunfield, C. and Kotler, D. P. (1992). Pathophysiology of the AIDS wasting syndrome, AIDS clin. Rev. 191-224.

[13]. Hawker, F. H, Stewart, P. Snitch, P. J, (1990).Effect of acute illness on selenium status. CriticalCare Medicine, 18:442-446

[14]. Hori, K., Hatfield, D., Maldarelli, F., et al. (1997). Selenium Supplementation Suppresses Tumor Necrosis Factor Alpha-Induced Human Immunodeficiency Virus Type 1 Replication in Vitro. AIDS Res Hum Retroviruses 13(15) 1325-32.

[15]. Khalili, A., Soulbakhsh, M.,Hajiabdoibaghi, S., Dashti - Khavidaki, A.,Poor-Zare, A. A.Saeedi and Sharififar, R. (2008). Nutritional status and serum zinc and selenium levels in Iranian HIV infected individuals. BMC in infectious diseases. 8:165

[16]. Kruzich, L. A., Marquis, G. S., Wilson, C. M. and Stephensen, C. B. (2004). HIV - infected US youth are at high risk of obesity and poor diet quality: a challenge for improving short and long term health outcomes. JAm Diet Assoc. 104:1554-1560

[17]. Licastro, F., Chiricolo, M., Morini, M.C., Capril, I., Davis, L.J., Conte, R., Mancini, R., Melotti, C., Parente, R., Serra, R. and Carpene, E. (1995). Influence of age and health on immune functions and trace elements. Gerontology, 41(4): 235-241.

[18]. Macallan, D. C. (1999). Wasting in HIV - infection and AIDS. J. Nutr. 129:2385-2425.

[19]. Maret, W. and Standstead, H.H. (2006). Zinc requirements and the risk and benefit of zinc supplementation. Journal of Trace elements and Medical Biology, 20: 3-18. 
[20]. Moulder, K and Steward M.W (1989). Experiential Zinc deficiency: Effect on cellular responses and affinity of hundred antibodies.Clinic Exp. Immune 77:269-274.

[21]. Olmsted. L., Schravzer, G., Floresarce, M.and Dowd, J. (1988). Selenium Supplementation of Symptomatic human immunodeficiency virus in infected patients. Biol trace elem Res 20:59-65.

[22]. Palm. H. J., Paulson, E. K. (1997).Reactive oxygen species and gene expression. Nutr. Rev 55:353-361.

[23]. Prasad, A.S. (1993). Essential and toxic trace elements in human health and disease. ${ }^{\text {st }}$ Edition. New York: Wiley - Liss, $138-146$.

[24]. Rayman, M. P. (2000). The importance of selenium to human health. The Lancet 356 (9225): 233-41.

[25]. Shisler, J. L., Senkevich, T. G., Berry, M. J. andMoss,B. (1998). Ultraviolet induced cell death blocked by a selenoprotein from a human dermatotrophic Pox Virus. Science 29:102-105.

[26]. Stanbullian, M., Fella, S. and Slobodianik, W. H. (2007). Nutritional status in patients with HIV infection and AIDS Nutr. 98:140143

[27]. Tanaka, Y., Shiozawa, S. and Morimoto, I. (1990). Role of zinc in interleukin 2 (IL-2)-mediated T-Cell activation. Scand J. Immunol 31 (5) 547-552.

[28]. Williams, J., Suganya, S.,Thirunavukkarasu, D. and Jeevithan, S. (2007). Estimation of serum Ferrium in HIV/AIDS patients. Indian Journal of Sexually transmitted diseases 28(1):23-25. 